\title{
The role of the human acetylation polymorphism in the metabolic activation of the food carcinogen 2-amino-3-methylimidazo[4,5-f]quinoline (IQ)
}

\author{
Markus R.Probst ${ }^{1}$, Martin Blum, Ingrid Fasshauer ${ }^{2}$, \\ Daniel D'Orazio, Urs A.Meyer and Dieter Wild ${ }^{2,3}$ \\ Department of Pharmacology, Biocenter of University of Basel, \\ Klingelbergstrasse 70, $\mathrm{CH}-4056$ Basel, Switzerland, and ${ }^{2}$ Institute of \\ Pharmacology and Toxicology, University of Würzburg, Versbacher \\ Strasse 9, D-8700 Würzburg, Germany \\ ${ }^{3}$ To whom reprint requests should be sent \\ 'Present address: University of California Los Angeles, Laboratory of \\ Biomedical and Environmental Sciences, 900 Veteran Ave, Los Angeles, \\ CA 90024, USA
}

The metabolic activation of the heterocyclic food carcinogen 2-amino-3-methylimidazo[4,5-f]quinoline (IQ) by two human cytochrome P450 monooxygenases (P4501A1 and P4501A2) and two human $\boldsymbol{N}$-acetyltransferases (NAT1 and NAT2) was investigated. Various combinations of these enzymes were functionally expressed in COS-1 cells. DNA adducts resulting from the activation of IQ were assayed quantitatively by the ${ }^{32}$ P-postlabeling procedure. The highest adduct frequency was observed in cells expressing both CYP1A2 and NAT2. CYP1A2 in combination with NAT1 was 3-6 times less active. When expressed alone these enzymes gave rise to low adduct frequencies. Experiments with $N$-acetyl-IQ as substrate suggest that NAT1 and NAT2 in addition to their kmown rołe in $N$-acetylation display arylhydroxamic acid $N, O$ acetyltransferase (AHAT) activity. Quantitative differences in adduct formation between IQ and $\boldsymbol{N}$-acetyl-IQ indicated that metabolic activation of these arylamines preferentially occurs by P4501A2-catalyzed $N$-hydroxylation followed by

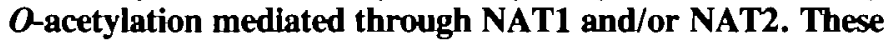
data, in combination with the known genetic polymorphism of NAT2, may explain the clinical observation that the acetylation polymorphism constitutes a risk factor in the carcinogenic activation of environmental mutagens.

\section{Introduction}

Frying of meat and fish results in the generation of heterocyclic arylamines (1), which present a major source of dietary carcinogens. Among a number of food-derived heterocyclic amines, 2-amino-3-methylimidazo[4,5-f]quinoline (IQ*) was found to be highly mutagenic in Salmonella typhimurium, and its carcinogenic potential was demonstrated in various rodent species and a primate $(2,3)$.

The effects of heterocyclic arylamines, like those of other arylamines, require metabolic activation by drug-metabolizing enzymes. It is generally accepted that the ultimate mutagens/carcinogens are electrophilic arylnitrenium ions, which can react with DNA and form adducts (4-6). Reactions involved in the metabolic activation include $N$-hydroxylation and $N$ - and $O$ acetylation (Figure 1), catalyzed by microsomal monooxygenase enzymes of the cytochrome P4501A family (for review see 7,8),

-Abbreviations: IQ, 2-amino-3-methylimidazo[4,5-f]quinoline; NAT, $N$ acetyltransferase; RFLP, restriction fragment length polymorphism; AHAT, arylhydroxamic acid $N, O$-acetyltransferase; OAT, $O$-acetyltransferase. and acetyl coenzyme A-dependent arylamine $N$-acetyltransferases (NATs) in liver cytosol (9). In the case of IQ and related heterocyclic arylamines, $N$-acetylation appears to be a minor metabolic pathway $(10,11)$. Considerable interindividual variations in the activities of these enzymes has been observed caused either by environmental conditions or genetic polymorphisms. P4501A1 is induced by cigarette smoking, and individuals with genetically controlled high inducibility are at higher risk of developing cigarette-induced bronchogenic carcinoma (12). A restriction fragment length polymorphism (RFLP) has been reported in the human CYP1A1 gene downstream of the coding region $(13-15)$. The association of this RFLP with an increased incidence of bronchogenic carcinoma has been observed in some but not all populations tested (12). Point mutations in the NAT2 gene, resulting in decreased enzyme protein levels (16), are responsible for the acetylation polymorphism, which divides the population into so-called 'rapid' and 'slow' acetylators. Between 40 and $70 \%$ of individuals in Caucasian populations are slow acetylators (17). Slow acetylators display impaired metabolism of a variety of arylamine and hydrazine drugs and chemicals. These include many therapeutically useful drugs (for review see 17,18 ), as well as potential arylamine carcinogens present in dyes, antioxidants, pesticides and explosives (19).

There is circumstantial evidence for a link between rapid acetylator status and certain diseases, e.g. colorectal cancer $(20-22)$. A second human NAT gene, NAT1, is not affected by the acetylation polymorphism, and does not contribute to the

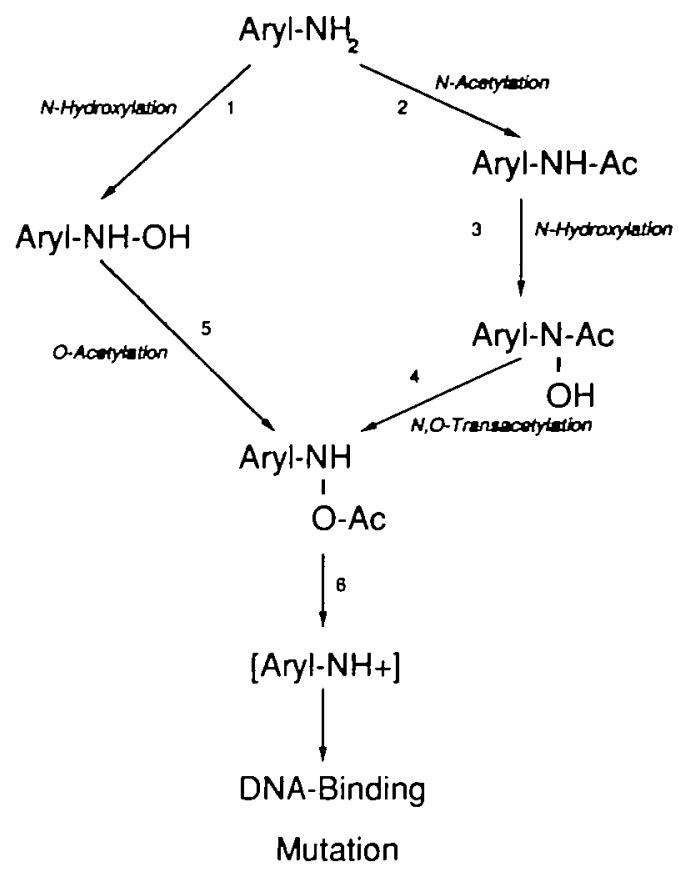

Tumor Initiation

Fig. 1. Metabolic activation of arylamine carcinogens. 
acetylator status $(23,24)$. The availability of the cloned NAT1/NAT2 genes allows us to test in a cell culture situation, which one of these genes is involved, if at all, in the metabolic activation of IQ. Upon transfection of different combinations of NAT and CYP1A genes, P4501A2 and NAT2 resulted in the highest IQ-DNA adduct frequencies. This suggests that the human acetylation polymorphism may affect the carcinogenic action of the food mutagen IQ.

\section{Materials and methods}

\section{Chemicals}

IQ was purchased from WAKO Pure Chem. Industries, Ltd (Neuss, Germany). $N$-Acetyl-IQ was prepared from IQ and acetic anhydride, and was further purified by chromatography on silica gel. Phenoxazone ethers and resonufin were purchased from Pierce Chemicals. All other chemicals were of HPLC or analytical grade quality and obtained from local suppliers.

Functional expression of NATI, NAT2 CYPIAI and CYPIA2 in monkey kidney COS-1 cells

COS-1 cells were cultured and transfected by the DEAE-dextran/chloroquine method as described (25). The human NAT1 and NAT2 expression constructs in the vector $\mathrm{p} 91023$ (B) were as described (23). cDNA clones encoding human CYP1Al (26) and CYP1A2 (27) were kindly provided by D.W.Nebert and F.J.Gonzales (NCI, NIH Bethesda, MD), and were subcloned into p91023(B). Cultures were treated with IQ or $N$-acetyl-IQ (dissolved in ethanol) $50 \mathrm{~h}$ after transfection, and cells were harvested 9-12 h later.

Enzyme assays and detection of expressed proteins on Westem blots Enzyme activity of expressed NAT proteins was determined using sulfamethazine as a substrate and quantitated using a HPLC assay as described (28).

P4501A1 and P4501A2 proteins in transfected COS-1 cultures and in microsomes prepared from kidney donor liver (KDL35) were identified by immunoreaction on Western blots with a rabbit antiserum raised against the corresponding rat P4501A1 (P450c) enzyme. This antiserum recognizes both human P4501A1 and P4501A2 proteins. Their enzymatic activities were determined by dealkylation of phenoxazone ethers 7-methoxy- and 7-ethoxyresorufin as described by Burke et al. (29). Deacetylation of $N$-acetyl-IQ was measured by reversed-phase HPLC (MN 5-C18 Macherey-Nagel, Germany) by isocratic elution using $50 \mathrm{mM}$ sodum acetate/methanol $(40: 60) \mathrm{pH} 6.3$ as mobile phase and UV detection at $\lambda=254 \mathrm{~nm}$.

DNA isolation and ${ }^{32} P$-postlabeling

Cell pellets were homogenized by means of an Ultra-Turrax, and treated with RNase A, RNase $T_{1}$ and proteinase $K$. DNA was extracted with phenol/chloroform

$$
\text { A } B \text { C } \quad D^{-} \text {E }
$$

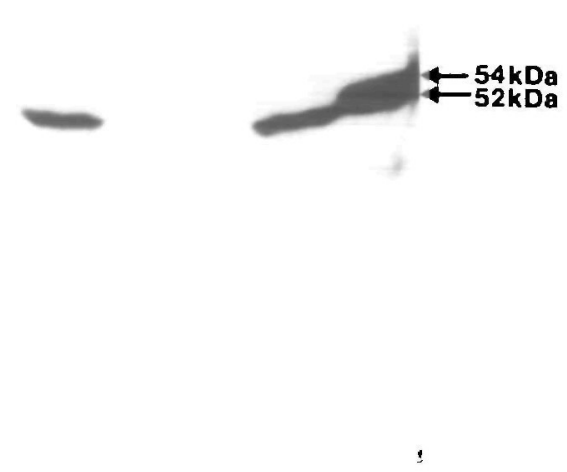

Fig. 2. Immunoreaction on Western blots of CYPIA1 and CYPIA2 in human liver microsomes and upon expression of the respective cDNAS in COS-1 cells. Homogenates of COS-1 cells transfected with cDNAS encoding CYPlAl in sense (lane A) and antisense orientation (lane B), and CYPIA2 in antisense (lane $C$ ) and sense (lame D) orientation, as well as human liver microsomes (lane E) were subjected to SDS-PAGE $(150 \mu \mathrm{g}$ of COS-1 homogenates and $50 \mu \mathrm{g}$ microsomal protein), transferred to nitrocellulose and immunoreacted with a polyclonal rabbit antiserum raised against purified rat P4501Al. and precipitated with ethanol. After digestion of the DNA to 3 '-nucleotides with micrococcus endonuclease and spleen exonuclease (30), an aliquot of the digest equivalent to $4 \mu \mathrm{g}$ was labelled with $100-120 \mu \mathrm{Ci}\left[\gamma^{32} \mathrm{P}\right] \mathrm{ATP}$ (sp. act. 3000 $\mathrm{Ci} / \mathrm{mmol}$; Amersham, Braunschweig, Germany) and by use of T4 polynucleotide kinase (Pharmacia). The intensification procedure was applied according to Randerath et al. (31). Four-directional TLC separation of the adducts was performed on PEI-cellulose sheets (Macherey-Nagel) with the following solvents: DI, $1 \mathrm{M}$ sodium phosphate, $\mathrm{pH} 6.8$; $\mathrm{D} 3,3.8 \mathrm{M}$ lithium formate, $6.8 \mathrm{M}$ urea, $\mathrm{pH} 3.4$; $\mathrm{D} 4,0.6 \mathrm{M}$ sodium phosphate, $0.38 \mathrm{M}$ Tris $-\mathrm{HCl}, 6.5 \mathrm{M}$ urea, $\mathrm{pH} 8.2$; D5, 1.7 M sodium phosphate, $\mathrm{pH}$ 6.0. After detection of adducts by autoradiography, spots were excised and quantitated by Cerenkov counting; intensification factors required for the quantitative analysis were determined in each experiment by use of a highly IQ-modified DNA (32).

\section{Results}

\section{Metabolic activation of IQ}

Figure 1 shows the proposed enzyme reactions involved in the metabolic activation of arylamines such as IQ. The first step of metabolism of arylamines can either be an $N$-hydroxylation (reaction 1 in Figure 1 ) or an $N$-acetylation (reaction 2 in Figure 1). Reaction 1 may be catalyzed by either P4501A1 or P4501 A2 $(7,8)$, and it has been shown that liver cytosolic NAT accounts for the $N$-acetylation reaction (24). The $N$-arylacetamide resulting from reaction 2 serves as substrate for P4501A1 or P4501A2, and $N$-hydroxylation yields the respective arylhydroxamic acid (reaction 3, Figure 1). The two pathways converge through reactions $4(N, O$-transacetylation) and $5(O$ -

A

\section{CYP 1 A 1}

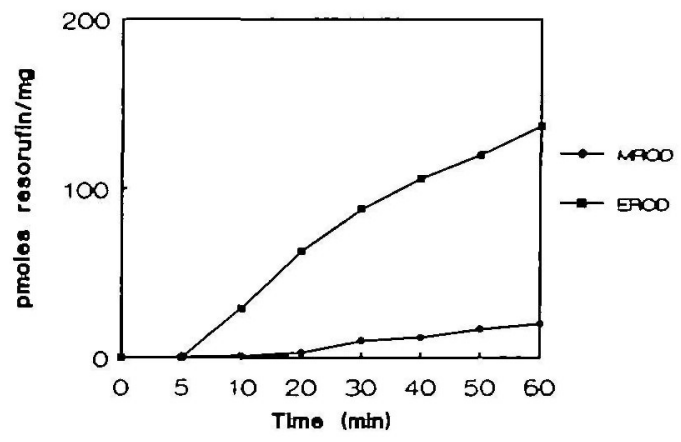

B
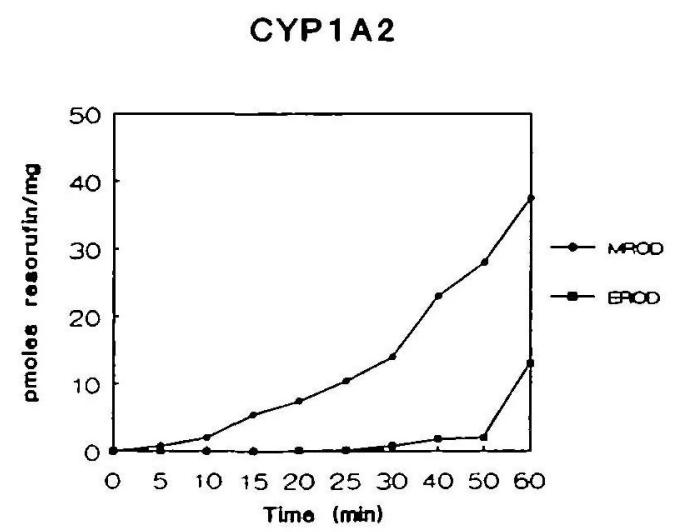

Fig. 3. Expressed cytochrome P4501A1 and cytochrome P4501A2 are functionally active in COS-1 cells. Homogenates of COS-1 cells transfected with CYPIA1 (A) and CYPIA2 (B) were incubated with methoxyresorufin $(\bullet)$ and ethoxyresorufin ( $\mathbf{D}$ ), and formation of the dealkylated products was determined at the time points indicated. Note: P4501A1 preferentially metabolized ethoxyresorufin, whereas P4501A2 displayed hugher activity with methoxyresorufin. 
acetylation) to yield the product, $N$-acetoxy- $N$-arylamine. Both of these reactions have been attributed to the activity of cytosolic NAT in hamster and rabbit $(33,34)$, whereas no such correlation could as yet be established for the human NAT enzymes. Spontaneous degradation of $N$-acetoxy- $N$-arylamines (reaction 6 in Figure 1) leads, presumably via unstable arylnitrenium ions $(4-6)$, to the formation of DNA adducts.

COS- 1 cell cultures provide an in vitro system to analyze IQadduct formation

COS-1 cells were used to analyze the involvement of the proposed enzymes in the above-mentioned reactions in an in vitro system,

Table I. Formation of IQ-nucleotide adducts in COS-1 cells transfected with cytochrome P450 monooxygenase and $\mathrm{N}$-acetyltransferase genes

\begin{tabular}{lccl}
\hline Gene combinations & \multicolumn{3}{l}{ Adducts/10 $0^{8}$ nucleotides $( \pm \mathrm{SD})$} \\
\cline { 2 - 4 } & IQ $100 \mu \mathrm{M}$ & IQ $10 \mu \mathrm{M}$ & N-Acetyl-IQ $10 \mu \mathrm{M}$ \\
\hline CYP1A1 & $7.3 \pm 0.2$ & ND & ND \\
CYP1A2 & $13.6 \pm 2.3$ & 0 & 0 \\
NAT1 & $1.7 \pm 0.4$ & ND & 0 \\
NAT2 & $1.6 \pm 0.2$ & ND & 0 \\
CYP1A2 + NAT1 & $81.6 \pm 5.9$ & $9.3 \pm 0.7$ & $1.0 \pm 0.2$ \\
CYP1A2 + NAT2 & $250.3 \pm 28.8$ & $57.2 \pm 5.8$ & $14.4 \pm 1.3$ \\
\hline
\end{tabular}

COS-1 cells were transfected with CYP1A1, CYP1A2, NAT1 and NAT2, either alone or in the combination indicated. Cultures were incubated in the presence of 10 or $100 \mu \mathrm{M}$ IQ or $N$-acetyl-IQ for $12 \mathrm{~h}$, followed by isolation of the DNA and analysis of IQ-adducts.

Note: the combination of CYP1A2 and NAT2 resulted in the highest adduct frequencies in all three experiments. Adduct formation with the acetylated IQ substrate still required the NAT enzyme(s), indicating their inherent $N, O$-transacetylase activities.

$\mathrm{ND}$, not done; 0 , no adducts detectable.

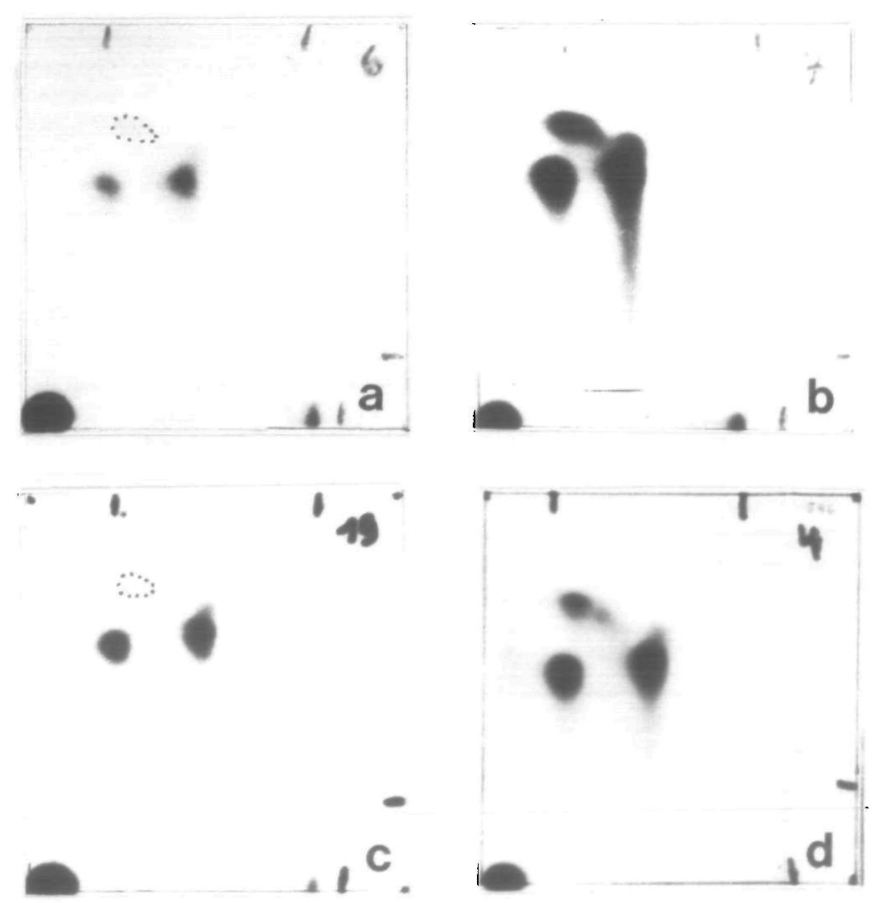

Fig. 4. Identical patterns of IQ and $N$-acetyl-IQ adducts in COS-1 cells expressing CYP1A2 + NAT1 and CYP1A2 + NAT2. Autoradiographs of IQ-DNA adducts separated by TLC. (a) COS-1 cells transfected with CYPIA2 + NAT1 (substrate: IQ, $10 \mu \mathrm{M}$ ); (b) COS-1 cells transfected with CYPIA2 + NAT2 (IQ, $10 \mu \mathrm{M}$ ); (c) COS-1 cells transfected with CYP1A2 + NAT2 (substrate: $N$-acetyl-IQ, $10 \mu \mathrm{M}$ ); (d) IQ adducts formed in the liver of a F344 rat $24 \mathrm{~h}$ after a $30 \mathrm{mg} / \mathrm{kg}$ oral dose of IQ; adduct frequency $123 / 10^{8}$ nucleotides. The origin of the chromatograms is in the lower lefthand comer. both individually and in combination. We have previously demonstrated that NAT1 and NAT2 can be functionally expressed in COS-1 cells, and that COS-1 cells have no detectable endogenous $\mathrm{N}$-acetylation activity (25). In this study, we have additionally analyzed the expression of CYP1A1 and CYP1A2 cDNAs in COS-1 cells. Immunoreaction on a Western blot of proteins expressed from the cDNAs using a polyclonal rabbit antiserum raised against the rat P4501A1 is shown in Figure 2. Protein bands of the expected mol. wts of 52 and $54 \mathrm{kDa}$ in cultures transfected with CYP1A1 (lane A, Figure 2) and CYP1A2 (lane D, Figure 2) respectively were detected. These were indistinguishable in electrophoretic mobility from microsomal proteins isolated from human liver (lane E, Figure 2), suggesting that in this particular liver both P4501A proteins were present. No immunoreactive proteins were detected in cultures transfected with the constructs in antisense orientation (lanes B and C, Figure 2). Cell homogenates of cultures transfected with CYP1A1 or CYP1A2 both displayed enzyme activity with the substrates 7-methoxy- and 7-ethoxyresorufin (Figure 3). Homogenates of untransfected cells and cells transfected with cDNAs in antisense orientation did not display any detectable activities with either substrate (not shown).

The highest DNA adduct frequency occurs in COS-1 cells transfected with CYP1A2 and NAT2

COS-1 cells were transfected with NAT and CYP1A genes individually and in the combinations shown in Table $I$. Transfected cultures were treated with IQ (at a concentration of $100 \mu \mathrm{M})$ and the resulting adduct frequencies determined (Table I, left-hand column). Transfections with NAT1 or NAT2 alone resulted in low levels of IQ-DNA adducts (1 - 2 adducts/ $10^{8}$ nucleotides; see Table I). Slightly more DNA adducts were found after transfection of COS-1 cells with either CYP1A1 or CYP1A2 (7-14 adducts/ $10^{8}$ nucleotides; Table I). From these experiments we conclude that COS- 1 cells have virtually no endogenous enzyme activity for the acetylation and hydroxylation of arylamines. Because expressed P4501A2 was twice as active as P4501A1, combinations of CYP1A2 and NAT genes were used in all further experiments. As shown in Table I, these combinations resulted in adduct frequencies 5-20 times higher than those obtained with single genes, and NAT2 was three times more effective than NAT1.

A lower IQ concentration $(10 \mu \mathrm{M})$ was applied in a second series of transfection experiments (Table I). Qualitatively, the same results were obtained, namely highest adduct frequencies following transfection of CYP1A2 in combination with NAT2. The chromatographic patterns of IQ-nucleotide adducts obtained after activation by P4501A2 and NAT1 and by P4501A2 and NAT2 were qualitatively identical (Figure 4a and b); the difference was merely quantitative. The same pattern had been found previously in liver DNA of rats that had received an oral dose of IQ (Figure 4d), and with that obtained from the IQ-related

Table II. COS-1 cells have no endogenous $N$-acetyl-IQ deacetylase activity

\begin{tabular}{lll}
\hline $\begin{array}{l}N \text {-Acetyl-IQ concentration } \\
(\mu \mathrm{M})\end{array}$ & COS-1 cell homogenate & $\begin{array}{l}\text { Human liver } \\
\text { microsomes }\end{array}$ \\
\hline 100 & $0.002^{\mathrm{a}}$ & $0.017^{\star}$ \\
200 & 0.002 & 0.085 \\
400 & 0.019 & 0.232 \\
\hline
\end{tabular}

Untransfected COS-1 cells were homogenized and assayed for endogenous deacetylase enzyme activity using chemically synthesized $N$-acetyl-IQ as substrate. Microsomes isolated from human liver were similarly analyzed. Numbers represent nmol IQ/mg protein/min. 
compounds nitro-IQ in Salmonella typhimurium and azido-IQ in calf thymus DNA $(32,35)$. The quantitatively most prominent, slow migrating adduct has been identified as $N$-(deoxyguanosin-8-yl)-IQ (36).

\section{NAT1 and NAT2 both display N,O-transacetylase (AHAT) enzyme} activity

Kinetic characterization of purified NAT enzyme activities from rabbit and mouse liver have suggested that the same enzyme has NAT, arylhydroxamic acid $N, O$-acetyltransferase (AHAT) and $O$-acetyltransferase (OAT) activities $(33,34)$.

We used the COS-1 expression system to address the question of whether human NATs have AHAT activity. The adduct formation by $N$-acetyl-IQ was studied, which, provided that this substrate is not deacetylated by COS- 1 cells, can be converted to an arylnitrenium ion only in the presence of AHAT activity (Figure 1). Therefore the $N$-acetyl-IQ deacetylase activity of COS-1 cells was tested and compared with that of human liver microsomes. As is evident from Table $\amalg, C O S-1$ cells display only minute endogenous deacetylase activities at all substrate concentrations tested, whereas significant activities were found in human liver microsomes.

In another series of transfection experiments $N$-acetyl-IQ was added to cultures and the resulting adducts were determined (Table I). Adducts were detected with combinations of CYP1A2 and either NAT1 or NAT2. NAT2 was 14 times as effective as NAT1, and overall frequencies were considerably lower $(1 / 4-1 / 9)$ than those observed with IQ at the same concentration $(10 \mu \mathrm{M})$. The chromatographic pattern of the $N$-acetyl-IQ-DNA adducts (Figure $4 c$ ) was the same as that of the IQ-DNA adducts. Thus, the same arylnitrenium ion was formed from IQ and $N$-acetyl-IQ and it can be concluded that both NAT1 and NAT2 display AHAT enzyme activity. The lower adduct frequency observed with $N$-acetyl-IQ compared to that observed with IQ is probably due to an efficient direct activation of IQ (via $N$-hydroxylation and $O$-acetylation) and a less efficient activation of $N$-acetyl-IQ (via $N$-hydroxylation and $N, O$ transacetylation).

\section{Discussion}

In the present report we used transient expression in COS-1 cells of each of four drug-metabolizing enzymes to study their role in the activation of the food mutagen and carcinogen IQ. Our experiments suggest that (i) human P4501A2 is more efficient than P4501A1 for $N$-hydroxylation of this heterocyclic amine; (ii) $N$-hydroxy-IQ is only weakly reactive towards DNA; (iii) the most efficient metabolic activation and DNA adduct formation is achieved with P4501A2 in combination with NAT2. Finally, we propose that NAT1 and NAT2 in addition to their known role in $N$-acetylation display $N, O$-transacetylase activity.

Our first finding is in keeping with published results obtained in rat and rabbit. When purified rat (37) and rabbit (38) P4501A1 and P4501A2 were used in the Salmonella mutagenicity assay with IQ, the rat P4501A2 enzyme was found to be 12 times, and the corresponding rabbit enzyme 8 times more efficient than P4501A1. Similarly, when mouse P4501A1 and P4501A2 enzymes were expressed in Hep G2 human hepatoma cells and used in the Salmonella assay with IQ, P4501 A2 was nine times as active as P4501 Al (39). Thus, the available evidence points to P4501A2 as the predominant physiological activator of IQ. $N$-Hydroxylation of IQ, obtained by expression of CYP1A2 alone (Table $)$, results in only minor formation of $1 Q$-nitrenium ions and DNA binding: an acetylation step is required as well. This is in agreement with mutagenicity data obtained in Salmonella 1716 strains with low, normal and high acetyltransferase activity, where the mutagenic activity of IQ (in the presence of rat liver S9) strongly depends on the acetylator status of the strain used (40).

The data presented indicate that the human acetylation polymorphism has to be considered an important factor in the metabolic activation of arylamine carcinogens. This becomes evident because (i) the polymorphic NAT2 in our analysis was about five times as effective as NAT1 in activating IQ into the arylnitrenium ion; and (ii) NAT2 possesses ten times as much $\mathrm{N}, \mathrm{O}$-transacetylase (AHAT) activity as NAT1, thus broadening the spectrum of reactions affected by the polymorphism.

In addition we suggest that NAT 1 and NAT2 can catalyze the hydroxylamine $O$-acetylation. This was concluded from the very low rate of IQ $N$-acetylation by rodent NATs $(10,41)$, and from the relatively high adduct frequencies found in our IQ experiments, which can only be explained by the presence of OAT activity (see Figure 1).

In conclusion, this study provides a mechanistic basis for the clinical observation that the acetylation polymorphism constitutes a risk factor in the metabolic activation of environmental and dietary mutagens/carcinogens.

\section{Acknowledgements}

We thank A.Demierre, M.Beer and D.Beer for expert technical assistance. This work was supported by the Swiss National Research Foundation (grant 32-31266.91). Work at the University of Würzburg was supported by the Deatsche Forschungsgemeinschaft (SFB 172 'Molekulare Mechanismen kanzerogener Primärveränderungen').

\section{References}

1. Felton,J.S. and Knize,M.G. (1990) Heterocyclic amine mutagens/carcinogens in foods. In Cooper, C.S. and Grover,P.L. (eds), Handboak of Experimental Pharmacology. Vol. 94, Springer, Berlin, pp. 471-502.

2. Sugimura,T., Sato,S. and Wakabayashi,K. (1988) Mutagens/carcinogens in pyrolysates of amino acids and proteins in cooked foods: heterocyclic aromatic amines. In Woo,Y., Lai,D.Y., Arcos,J.C. and Argus,M.F. (eds), Chemical Induction of Cancer. Academic Press, San Diego, Vol. iiiC, pp. 681-710.

3. Adamson,R.H., Thorgeirsson,U.P., Snyderwine,E.G., Thorgeirsson,S.S., Reeves,J., Dalgard,D.W., Takayama,S. and Sugimura,T. (1990) Carcinogenicity of 2-amino-3-methylimidazo[4,5-f]quinoline in nonhuman primates: induction of tumors in three maques. Jpn. J. Cancer Res., 81, 10-14.

4. Kadlubar,F.F. and Beland,F.A. (1985) Chemical properties of ultimate carcinogenic metabolites of arylamines and arylamides. In Harvey,R.G. (ed.), Polycyclic Hydrocartoons and Carcinogenesis, ACS Symposium series no. 283. American Chemical Society, Washington, DC, pp. 341-370.

5. Krick, E. (1965) On the interaction of $N$-2-fluorenylhydroxylamine with nucleic acids in vitro. Biochem. Biophys. Res. Commun., 20, 793-799.

6. Lutgerink,J.T., Stavenuiter,J.F.C., Zomer,G., Hamzink,M., van Dijk,P., Westra,J.G. and Kriek,E. (1989) Synthesis of heterocyclic $N$-acetoxyarylamines and their reactivity with DNA. Carcinogenesis, 10, 1957-1960.

7. Kadlubar,F.F. and Hammons,G.J. (1987) The role of cytochrome P-450 in the metabolism of chemical carcinogens. In Guengerich,F.P. (ed.), Mammalian Cyrochromes P-450. CRC Press, Boca Raton, FL, Vol. II, pp. 81-130.

8. Butler,M.A., Iwasaki,M., Guengerich,F.P. and Kadlubar,F.F. (1989) Human cytochrome $\mathrm{P}^{450} 0_{\mathrm{PA}}(\mathrm{P} 4501 \mathrm{~A} 2)$ the phenacetin- $O$-deethylase is primarily responsible for the hepatic 3 -demethylation of caffeine and $\mathrm{N}$-oxidation of carcinogenic arylamines. Proc. Natl. Acad. Sci. USA, 86, 7696-7700.

9. Weber,W.W. (1987) The Acetylator Genes and Drug Response. Oxford University Ptess, New York.

10. Kato,R. (1986) Metabolic activation of mutagenic heterocyclic aromatic amines from protein pyrolysates. CRC Crit. Rev. Taxicol., 16, 307-348.

11. Turesky,R.J., Bracco-Hammer,I., Markovic,J., Richli,U., Kappeler,A.-M. and Welti,D.H. (1990) The contribution of N-oxidatron to the metabolism of the food-bome carcinogen 2-amino-3,8-dimethylimidazo[4,5-f]quinoxaline in rat hepatocytes. Chem Res. Taricol., 3, 524-535.

12. Nebert,D.W., Petersen,D.D. and Puga,A. (1991) Human AH locus polymorphism and cancer: inducibility of CYPIAl and other genes by combustion protucts and dioxin. Pharmacogenetics, 1, 68-78.

13. Kawajiri,K., Nakachi,K., Kazure,I., Yoshiı,A., Shinoda,N. and Watanabe.J. 
(1990) Identification of genetically high risk individuals to lung cancer by DNA polymorphisms of the cytochrome P4501Al gene. FEBS Lett., 263, $131-133$.

14. Hayashi,S., Watanabe,J., Nakachi,K. and Kawajiri,K. (1991) Genetic linkage of lung-cancer associated $M s p /$ polymorphisms with amino acid replacement in the heme binding region of the human cytochrome P4501Al gene. $J$. Biochem., 110, 407-411.

15. Tefre,T., Ryberg,D., Haufen,A., Nebert,D.W., Skaug, V., Brogger,A. and Borrensen, A.-L. (1991) Human CYP1A1 (cytochrome P, 450) gene: lack of association between the $\mathrm{Mspl}$ restriction fragment length polymorphism and the incidence of lung cancer in a Norwegian population. Pharmacogenetics, 1, 20-25.

16. Blum,M., Demierre,A., Grant,D.M., Heim,M. and Meyer,U.A. (1991) Molecular mectranism of slow acetylation of drugs and carcinogens in humans. Proc. Natl. Acad. Sci. USA, 88, 5237-5241.

17. Evans,D.A.P. (1989) N-Acetyltransferase. Pharmac. Ther., 42, 157-234.

18. Meyer,U.A. (1990) Genetic polymorphisms of drug metabolism. Fundam. Clin. Pharmacol, 4, 595-615.

19. National Academy of Sciences (1981) Aromatic Amines: an Assessment of the Biological and Environmental Effects. National Academy Press, Washington, DC.

20. Wohlleb,J.C., Hunter,C.F., Blass,B., Kadlubar,F.F., Chu,D.Z.J. and Lang,N.P. (1990) Aromatic amine acetyltransferase as a marker for colorectal cancer: environmental and demographic associations. Int. J. of Cancer, 46, $22-30$.

21. Lang,N.P., Chu,Z.J., Hunter,C.F., Kendall,D.C., Flammang,T.J. and Kadlubar,F.F. (1986) Role of aromatic amine acetyltransferase in human colorectal cancer. Arch. Surg., 121, 1259-1261.

22. Ilett,K.F., David,B.M., Detchon,P., Castleden,W.M. and Kwa,R. (1987) Acetylation phenotype of cotorectal carcinoma. Cancer Res. , 47, 1466-1469.

23. Blum,M., Grant,D.M., McBride,W., Heim,M. and Meyer,U.A. (1990) Human arylamine $N$-acetyltransferase genes: isolation, chromosomal localization and functional expression. DNA Cell Bioh, 9, 193-203.

24. Grant,D.M., Blum,M., Beer,M. and Meyer,U.A. (1991) Monomorphic and polymorphic human arylamine $N$-acetyltransferases: a comparison of liver isozymes and expressed products of two cloned genes. Mol. Pharmacol., 39. $184-191$.

25. Blum,M., Grant,D.M., Demierre,A. and Meyer,U.A. (1989) N-Acetylation pharmacogenetics: a gene deletion causes absence of arylamine $\mathrm{N}$-acetyltransferase in liver of slow acetylator rabbits. Proc. Natl. Acad. Sci. USA, 86, $9554-9557$.

26. Jaiswal,A.K., Nebert,D.W. and Gonzalez,F.J. (1987) Hurnan $P_{3}-450$ : cDNA and complete amino acid sequence. Nucleic Acids Res., 14, 6773-6774.

27. Jaswal, A.K., Gonzalez,F.J. and Nebert,D.W. (1985) Human dioxin-inducible cytochrome $\mathrm{P}_{1}-450$ : complementary DNA sequence and amino acid sequence. Science, 228, 80-83.

28. Grant,D.M., Moerike,K., Eichelbaum,M. and Meyer,U.A. (1990) Acetylation pharmacogenetics: the slow acetylator phenotype is caused by decreased or absent arylamine $\mathrm{N}$-acetyltransferase in human liver. J. Clin. Invest., 85, $968-972$.

29. Burke,M.D., Tompson,S., Elcombe,C.R., Halpert,., Haaparanta,T. and Mayer,R.T. (1985) Ethoxy-, pentoxy-, and benzyloxyphenoxazones and homologues: a series of substrates to distingush between different induced cytochrome P-450. Biochem. Pharmacol., 34, 3337-3345.

30. Gupta,R.C., Reddy,M.V. and Randerath,K. (1982) ${ }^{32}$ P-Postlabelling analysis of non-radioactive aromatic carcinogen-DNA adducts. Carcinogenesis, 3, $1081-1092$.

31. Randerath,E., Agrarwal,H.P., Weaver,J.A., Bordelon,C.B. and Randerath,K. (1985) ${ }^{32}$ P-Postlabelling analysis of DNA-adducts persisting for up to 42 weeks in the skin, epidermis and dermis of mice treated topically with 7,12-dimethylbenz[ $[a]$ anthracene. Carcinogenesis, 6, 1117-1126.

32. Wild,D., Dirr,A., Fasshauer,I. and Henschler,D. (1989) Photolysis of arylazides and generation of highly electrophilic DNA-binding and mutagente intermediates. Carcinogenesis, 10, 335-341.

33. Glowinski,I.B., Weber,W.W., Fysh,J.M., Vaught,J.B. and King,C.M. (1980) Evidence that arylhydroxamic acid $N, O_{\text {acyltransferase and the genetically }}$ polymorphic $N$-acetyltransferase are properties of the same enzyme in rabbit liver. J. Biol. Chem. 255, 7883-7890.

34. Mattano,S.S., Land,S., King,C.M. and Weber,W.W. (1989) Purification and biochemical characterization of hepatic arylamine $N$-acetyltransferase from rapid and slow acetylator mice: identity with arylhydroxamic $N, O$ aceyltransferase and $N$-hydroxylamine $O$-aceryltransferase. Mol. Phamacol., 35, 599-609.

35. Dirr,A., Fasshauer,I., Wild,D. and Henschler,D. (1989) The DNA-addtucts of the food mutagen and carcinogen IQ (2-amino-3-methylimidazo(4,5-f)quinoline). Arch. Taxical., Suppl., 13, 224-226.

36. Synderwine,E.G., Roller,P.P., Adamson, R.H., Sato,S. and Thorgeirsson,S.S. (1988) Reaction of $N$-hydroxylamine and $N$-acetoxy derivatives of 2-amino-3-methylimidazo[4,5-f]quinoline with DNA. Synthesis and identification of $N$-(deoxyguanosin-8-yl)-IQ. Carcinogenesis, 9, 1061- 1065.

37. Yamazoe,Y., Shimada,M., Kamataki,T. and Kato,R. (1983) Microsomal activation of 2-amino-3-methylimidazo[4,5-f)quinoline. Cancer Res., $\mathbf{4 3}$, $5768-5774$

38. McMamus, M.E., Burgess, W., Snyderwine,E. and Suupans, I. (1988) Specificity of rabbit cytochrome $\mathbf{P}-450$ isozymes involved in the metabolic activation of the food derived mutagen 2-amino-3-methylimidazo $[4,5-f)$ quinoline. Cancer Res., 48, 4513-4519.

39. Ayoama, T., Gonzalez,F.J. and Gelboin,H.V. (1989) Mutagen activation by cDNA-expressed $\mathrm{P}_{1} 450, \mathrm{P}_{3} 450$ and $\mathrm{P} 450 \mathrm{a}$. Mol. Carcinogenesis, 1 , 253-259.

40. Wild,D., Watkins,B.E. and Vanderlaan,M. (1991) Azido- and nitro-PhIP, relatives of the heterocyclic arylamine and food mutagen PhIP-mechanism of their mutagenicity in Salmonella. Carcinogenesis, 12, 1091-1096.

41. Turesky,R.J., Lang,N.P., Burter,M.A., Teitel,C.H. and Kadhubar,F.F. (1991) Metabolic activation of carcinogenic heterocyclic aromatic amines by human liver and colon. Carcinogenesis, 12, 1839-1845.

Received on April 30, 1992; revised on June 11, 1992; accepted on July 2, 1992 